\title{
SOME COMMENTS ON THE BRITISH TELEVISION ACT, I954
}

DenNis LLOYD*

A careful reading of the contents of the Television Act, $1954,{ }^{1}$ reveals a remarkable collection of vague and ill-defined duties, as well as other provisions, which may occasion surprise to the vigilant reader and which certainly are deserving of at least brief note and comment. It is the object of this article to draw attention to some of the more conspicuous of such matters.

\section{Inderendent Television Authority}

\section{A. Functions}

Section I of the Act provides for creation of the Independent Television Authority and lays down its functions. ${ }^{2}$ The Authority is a body corporate, ${ }^{3}$ and it is not to be treated as exercising functions on behalf of the Crown for the purpose of the enactments and rules of law relating to the privileges of the Crown. ${ }^{4}$ The object of this latter provision is to avoid the effect of certain presumptions which might otherwise apply. For example, the Crown is presumed not to be bound by any Act of Parliament unless there is express provision or a necessary implication to this effect; and this presumption also extends to any body which can be regarded as a mere agent of the Crown. ${ }^{5}$ The Crown in this context really means the Executive Government.

The functions of the Authority are somewhat hazily defined as to provide, for a period of ten years, television broadcasting services, "additional to those of the British Broadcasting Corporation and of high quality, both as to the transmission and as to the matter transmitted." Not surprisingly, no criterion is afforded as to how such quality is to be assessed or by whom, and this provision, like many others in the Act, may be regarded as a pious hope or as brutum fulmen, according to whether one adopts the viewpoint of the legislator himself or of the aggrieved viewer desirous of securing the implementation of this particular statutory duty. As the enforceability of this duty gives rise to questions similar to those evoked by other provisions of the Act, it is proposed to postpone any general comment on this matter until some of the other detailed provisions of the Act have been referred to.

- LL.B. 1935, University of London; B.A. 1937, M.A. 1941, Cambridge University. Of the Inner Temple, Barrister-at-Law, Quain Professor of Jurisprudence, University of London.

12 \& 3 ELIz. 2, c. 55.

Id. $\S \mathrm{x}$.

'Id, First Sched., par. I.

IId. $\S \mathrm{r}(\mathrm{I2})$.

${ }^{5}$ See Tamlin v. Hannaford, [1949] 2 All E.R. 237.

- 2 \& 3 Eurz 2, c. 55, S I(I). 


\section{B. Membership}

It will also be observed that by section one the members of the Authority are to be appointed by a Minister of the Crown, viz., the Postmaster-General, from persons "appearing to him" to be qualified for the office. They are to hold offices for such period, not exceeding five years, as the Postmaster-General may fix when he appoints them; but he may at any time direct that any member shall cease to hold office. The casual reader may, therefore, be pardoned if he reaches the conclusion that the word "independent" in the designation of the Independent Television Authority refers to independence from the $B B C$, and not from the Government. This view, however, would not be altogether well-founded, for it appears to be the general policy of the Act that the I.T.A. should, broadly speaking, function independently, subject to certain specific powers of government control conferred by section nine. Thus, under this section, any Minister may require the Authority to broadcast any specified announcement; or, in the case of the Postmaster-General, to refrain from broadcasting any matter or class of matters specified. The Postmaster-General may also give directions as to the maximum and minimum times of broadcasting; and there are other powers specifically conferred on the Postmaster-General under the Act. Moreover, the same general policy on the answerability of Ministers for the activities of independent quasi-governmental statutory bodies applies to the I.T.A. as to such other bodies as the BBC itself, or nationalized corporations like the Transport Commission. The established rule here is that the relevant Minister can be questioned in Parliament on broad issues of policy, but not as to the day-to-day functioning of the statutory body. ${ }^{7}$

Members of Parliament and Governors of the $\mathrm{BBC}$ are disqualified from becoming members of I.T.A. ${ }^{8}$ Also, the Postmaster-General must satisfy himself that members of the I.T.A. have no "financial or other interest" likely to prejudice the discharge of their duties. How he is to do this and what happens if he does not, nowhere appears, save that the Postmaster-General has power to require such information as he considers necessary from any member or proposed member. Failure to comply would presumably result in nonappointment, or dismissal, in the case of an existing member. The Postmaster-General is also solemnly adjured to have particular regard to a member having an interest in any advertising agency, or in any business concerned with the manufacture or sale of wireless equipment, or whose business is that of a program contractor. The reason for the first and third of these is fairly obvious; less apparent is why the owner of a number of retail shops selling radios is regarded by Parliament as being probably unsuitable to act as a member of I.T.A. The meaning of "financial or other interest" is far from clear; it is, however, probably wide enough to cover a shareholder in a company, and for this purpose, it can be compared with the far narrower phrase, "independent as to finance," in section 5(2), which is referred to later in this article.

${ }^{7}$ See John A. G. Griffiti and Harky Street, Principles of Administrative LnW 285 (1952).

${ }_{2} \& 3$ Ezuz. 2, c. 55, $\$$ I(6). 


\section{Programming Criteria}

Section three is an interesting section, imposing on the I.T.A. a series of duties that would probably baffle a Solomon. Among other things, the I.T.A. is required to insure that any programs broadcast, ${ }^{9}$

(a) do not offend against good taste or decency, encourage crime or disorder, offend public feelings or refer offensively to any living person; (Would this include references to notorious criminals?)

(b) maintain a proper balance as to subject matter and a high general standard of quality; (A proper balance as to what against what, one may ask. And what is a proper balance, and just how high is a high general standard? Like Pontius Pilate, we need not pause for an answer, for none is vouchsafed.)

(c) present any news with "due" accuracy and impartiality; (The word "due" is almost too good to be true. What degree of inaccuracy is permissible before it becomes "undue"?)

(d) contain "proper" proportions of British origin and performance; (How much alien intrusion is to be borne before the limits of propriety are exceeded?)

(e) preserve due impartiality as regards matters of political or industrial controversy or relating to current public policy; (It may surprise readers that a program designed to encourage increased roadbuilding has recently been banned by I.T.A. on this account.)

(f) include no matter designed to serve the interests of any political party, except as to relays of the BBC's series of party political broadcasts, and as to "properly balanced" discussions where the participants put forward arguments of a political character. (Presumably, in assessing the relative weight of the contestants and the force of their arguments, to adopt a favorite judicial phrase, "no nice scales will be used.")

It is indeed difficult to take very seriously this solemn enactment of the legislator's own doubts about the possible implications of injecting the system of commercial television into the national life. Certainly, this pompous asseveration of the need for "proper" standards, within any hint as to what they are or as to how they are to be judged, would appear on the face of it to confer on the I.T.A. a kind of over-all censorship likely to be of minimum effect in preserving cultural standards, but capable of being used in a Mother Grundyish or pedantic fashion so as, for instance, to impede the showing of serious drama which might offend decency in the sense sometimes invoked under the Obscenity Act of $1857,{ }^{10}$ or programs which are deemed to overtip by a hair's breadth the elusive quality of "due impartiality."

Religious services or propaganda relating to matters of a religious nature, and also items designed to give publicity to the need of charities, are not to be included without the prior approval of the Authority. ${ }^{11}$

- Id. $\varsigma_{3}(\mathrm{r})$.

${ }^{10} 20$ \& 21 Vict., c. 83. Cf. the author's article, Obscenity and the Law, 9 CUrRgnt Legar ProBLEMS 75 (1956).

${ }_{11} 2$ \& 3 ELIz. 2, c. $55,53(4)$. 
Section eight provides for the appointment of certain advisory committees to afford much-needed assistance to the I.T.A. in its negotiation of the various tightropes on which it is ordered to parade under section three. These include a committee representative of "the main streams of religious thought" in the United Kingdom (a category which Parliament wisely refrains from indicating more specifically) to advise on matters of a religious nature to be included in broadcasts; a committee representative of persons and bodies concerned with standards of advertising to advise the I.T.A. as to this and to prepare and submit to the Authority a code of conduct of this purpose; ${ }^{12}$ and also a committee representative of those concerned with child welfare and education to advise as to programs for the young. There follows the delightfully nebulous duty of the Authority to comply and secure compliance with the recommendations of any such committees, subject to such exceptions and modifications as may appear to the Authority to be necessary or proper.

\section{Advertisements}

Concerning the advertisements to be included in the broadcast program, apart from any code of behavior recommended by the committee referred to in section eight, a number of rules are laid down in the Second Schedule to the Act. These contain quite a few ill-defined obligations of the type which, as we have seen, permeates almost every aspect of this well-meaning but sloppily-drafted measure. Thus, advertisements must be "clearly distinguishable" from the rest of the program; they may only be inserted at the beginning or end of the program or in "natural breaks" therein; there must be no "unreasonable discrimination" against or in favor of any particular advertiser; and no advertisement is to be directed towards any religious or political end or relate to any industrial dispute. The charges to be made by program contractors are to accord with tariffs fixed by them and published in such form and manner as the Authority may determine.

The Authority also has the duty to consult with the Postmaster-General as to the classes and descriptions of goods or services which must not be advertised and the methods of advertising which must not be employed; and the Authority must carry out any directions of the Postmaster-General in these respects. ${ }^{13}$ This is to enable the Postmaster-General to assure that television is not used for advertising goods, such as contraceptives, or services such as those of marriage bureaus, which are regarded as unsuitable to be advertised by the medium of television. ${ }^{14}$

\section{E. Program Contractors}

Section five is a section that raises some nice problems. The section imposes on the Authority the duty "to do all that they can" to secure that persons who are disqualified persons do not become or continue as program contractors, either alone or in partnership with others. Broadly speaking, the following persons are disqualified:

${ }^{19}$ A code to this effect was published in June 1955 entitled "Principles for Television Advertising."

182 \& 3 Elrz 2 ; c. 55 , \$ $4(5)$.

14 See "Principles of Television Advertising," stupra note 12, which have been approved by the Postmaster-General. 
(a) individuals not ordinarily resident in the United Kingdom and corporations incorporated outside the United Kingdom;

(b) advertising agents; and

(c) corporations under the control of any such persons as the foregoing, or having as their directors, officers, or servants anyone who is a disqualified person by. reason of being an advertising agent.

Some of the consequences of this provision seem a little strange. Thus, it would exclude as program contractors a partnership between Smith living in England and Jones who only spends three months a year in the United Kingdom, whatever their respective shares and voting rights in the partnership; while it would include a company registered in England, some of whose shareholders are foreigners residing abroad, provided they do not have control of the company. And two foreigners living in England could form a partnership to act as contractors within this provision, whereas a company merely registered abroad but whose undertaking, shareholders and directorate are located in England is excluded. Also, an English subject or corporation could not undertake a partnership with a person resident abroad or a foreign company for the purpose of acting as a contractor, but there is apparently nothing to stop them entering into any arrangement which falls short of a partnership, e.g., an agreement with a foreign company to hire equipment and pay a rent for it based on a percentage of net profits. ${ }^{15}$ It must, however, be emphasized that section $5(\mathrm{I})$ is only concerned with the question, who is a disqualified person, and that the Authority still retains an unqualified discretion as to accepting or rejecting anyone who applies to become a program contractor.

Section 5(2) lays down the Authority's duty to do "all they can" to secure that, in supplying programs, there is "adequate competition" between a number of program contractors "independent of each other both as to finance and as to control." Save that the meaning of "control" is later defined with reasonable precision in section nineteen, it would be difficult for a legislator to have expressed its wishes or intentions in more nebulous terms. Apart from the impossibility of knowing to what lengths the Authority is expected to go to fulfill its statutory duty, what constitutes "adequate competition" for this purpose, and what meaning can be ascribed to financial "independence"? It would seem that financial independence is not the same as a financial interest falling short of control; for even assuming that a minority shareholder can be said to have a financial interest in his company, ${ }^{16}$ it seems clear that in no real sense can the company be said to be in a state of dependence towards him. Hence, it would seem that there would be no want of adequate competition within the section merely because a particular program contractor was already a minority shareholder in another corporation, which is itself a program contractor. Presumably, however, there would be some measure of financial dependence within the

${ }^{10}$ See Partnership Act, I890, 53 \& 54 Vrcr., c. 39, § 2(3).

${ }^{10}$ See, on this, the discussion in L. C. B.. Gower, Principles of Modern Company Law 3 Ig et seq. (2d ed. 1957). 
section if one contractor (and possibly even a minority shareholder of such a contractor) had advanced money on loan to another contractor, whether by way of debentures or otherwise. And what if a single individual holds considerable stock in several corporations that act as program contractors? One cannot help feeling that Parliament should either have made up its mind clearly what type of financial interlocking it desired to exclude or have simply left it to the I.T.A.'s general discretion to see that competition was maintained; the existing provision seems to provide for the worst of both worlds by merely encroaching on the I.T.A.'s discretion and, at the same time, affording too narrow a test of the type of interlocking arrangement which might at some time or another be regarded as undesirable.

\section{F. I.T.A. Contracts}

As to the contracts to be made between the I.T.A. and the program contractors who are to provide the programs to be broadcast from the Authority's transmitter, the Act lays down a number of provisions that all such contracts are to contain. ${ }^{\mathbf{1 7}}$ These include such matters as provisions to enable the Authority to require advance copies of scripts and programs; to require the making of visual and sound records of programs and the production of these to the Authority for examination or reproduction; and for reserving to the Authority power to forbid any broadcasts or to require that nothing shall be broadcast without its previous approval. An interesting requirement is that all contracts must provide for a penalty clause in the event of breaches by the contractor. ${ }^{18}$ The maximum penalty is not to exceed $£ 500$ on a first occasion, $f_{1}, 000$ on a second occasion, and $f_{1}, 500$ on any subsequent occasion. Further, any dispute as to the liability to pay a penalty, or as to the amount payable, is to be determined by arbitration. At common law, such a penalty clause would almost certainly have been held to be void as being in terrorem and not a genuine preestimate of the probable damage which might be suffered by the Authority. ${ }^{10}$

Every contract is also to contain a provision reserving to the Authority the absolute right, if breaches have occurred, to determine or suspend the transmission of the contractor's programs, without compensation. ${ }^{20}$ Before the Authority can take this drastic step, however, penalties must have been paid or have been adjudged payable on at least three separate occasions, and the contractor must also have been given a reasonable opportunity of making representations. This right is quite apart from the general right of the Authority to accept as a repudiation of the contract any breach which goes to the root of the contract. ${ }^{21}$

\section{G. Legal Nature of Duties}

Reference has already been made to the many rather vaguely-formulated duties imposed on the Authority under the Act and to the problem whether such duties can be regarded as in any sense legally enforceable. A typical example is the duty,

\footnotetext{
${ }^{17} 2$ \& 3 ELIZ. 2, c. 55, Third Sched. $\quad{ }^{18} I d . \$ 6(2)$.

${ }^{10}$ See Dunlop Tyre Co., Ltd. v. New Garage Ltd., [1915] A.C. 79.

${ }^{20} 2 \& 3$ EIIZ. 2, c. 55, \$ 6(3). ${ }_{81}$ Id. \$ 6(4).
} 
already mentioned, to maintain, in regard to programs broadcast, a high general standard of quality. Can such a duty be enforced, and, if so, in what way, and by whom? Or is it no more than a mere pious expression of hope, incapable of legal execution?

It should be borne in mind in this connection that similar provisions are to be found enacted in a good many recent statutes, more particularly those dealing with nationalized industries. Thus, the Electricity Act of 1947 requires the Electricity Boards to perform such duties as promoting the use of all economical methods of generating electricity, ${ }^{22}$ the Transport Act, I947, provides that it is the general duty of the Transport Commission to provide an efficient, adequate and properly integrated system of public transport, ${ }^{23}$ and the Iron and Steel Act, 1953, imposes a similar duty on the Iron and Steel Corporation. ${ }^{24}$ It is noteworthy, however, that the latter two statutes take the precaution of adding words to the effect that nothing in these sections is to have the effect of creating any duty or liability enforceable in any court or tribunal. ${ }^{25}$ Although no such proviso is to be found in the Television Act, I954, it seems very doubtful indeed whether such a duty as that referred to is not of so vague and generalized a character as to be incapable of legal enforcement. Moreover, as pointed out, questions could not even be put in the House of Commons to the appropriate Minister, unless some issue of broad policy was involved, and not merely a question of day-to-day administration. ${ }^{26}$ However, a question as to whether a proper standard of quality was being maintained might well be regarded as a fundamental matter of policy for this purpose, and certainly it would seem to be a question more fit for debate in Parliament than for the application of legal process.

Other duties imposed on the Authority may, however, well be regarded as susceptible of more precise legal definition and, therefore, be legally enforceable in appropriate circumstances. ${ }^{27}$ For instance, the Authority, as already pointed out, has imposed on it the duty to "do all that they can to secure that there is adequate competition to supply programs between a number of program contractors independent of each other both as to finance and as to control."28 Whether a prerogative order such as mandamus or prohibition would lie in respect of an alleged failure to implement this duty is far from clear, ${ }^{29}$ but there seems no reason in principle why an action for a declaration and possibly an injunction might not lie in proper circumstances. ${ }^{30}$ Suppose, for instance, that the I.T.A. decided to give a new contract in respect of a new region to a company which is already a contractor in regard to another region, and that it is suggested that this will result in a lack of adequate competition as pro-

${ }^{22}$ Io \& II GEo. 6, c. $54, \S \mathrm{I}(6)(\mathrm{a})$. $\quad{ }^{23}$ ro \& II GEo. 6, c. $49, \S_{3}(\mathrm{x})$.

24 I \& 2 ELIZ. 2, c. I5, $\$ 3(\mathrm{I})(\mathrm{a})$.

${ }^{25}$ See II \& I2 Geo. 6, c. $49, \$ 3(5)$, and I \& 2 Eliz. 2, c. I5, $\$ 3(2)$.

${ }^{20}$ Sce p. 166 stupra.

37 Cf. South of Scotland Electricity Board v. British Oxygen Co., Ltd., [Y956] I W.L.R. Io6g.

28 2 \& 3 ELIz. 2, c. $55, \S 5(2)$.

${ }^{30}$ For the scope of these remedies, see Grifrith AND STrEet, op. cit. supra note 7, at 225-3I.

${ }^{30}$ Cf. Barnard v. National Dock Labour Board, [1953] 2 Q.B. 18. 
vided by the Act. In such a case, there seems no reason why the court should refuse to entertain consideration of this matter, and if jurisdiction is accepted, the court will have to determine as a fact, on such evidence as is made available, whether by granting the new contract to an existing contractor the Authority is doing all it can to secure adequate competition. Normally, a proceeding of this kind could be brought only at the instance of the Attorney General (possibly at the relation of some private party). ${ }^{31}$ If, however, a private party could show a sufficient personal or pecuniary interest in the matter, it may be that he could institute such proceedings in his own right. ${ }^{32}$ For instance, it may be arguable that another applicant for the contract, whose application has been rejected in favor of the existing contractor, might have a sufficient interest to sue in his own right. This might be of importance if the Attorney General (whose discretion is unfettered) refused to take proceedings. But this point can only be regarded as very doubtul. There is also the question whether a claim for damages could be brought in any circumstances. On the whole, this seems very unlikely, since it would probably be held that the Act does not impose such a duty for the benefit of private individuals as such, but merely for the benefit of the public at large. ${ }^{38}$

\section{II}

\section{IMPACT OF THE TElevision Act}

In attempting to assess the general impact of the Television Act on broadcasting in England as a whole, it is desirable to approach the question with some caution, as it may well be thought that insufficient time has yet passed to enable the ultimate outcome to be predicted with any degree of reliability. Nevertheless, certain trends are already apparent, and these are deserving of at least brief comment in a survey of this kind. First, a conspicuous result already clearly apparent is the effect of television on sound broadcasting. The latest figures show a drop in the average number of sound listeners in the last three years from $9,000,000$ to $3,500,000 .^{34}$ In the last year, from June 1956 to June 1957 , there has been a drop of about 700,000. ${ }^{35}$ These figures are already having marked repercussions on $\mathrm{BBC}$ plans for future sound broadcasting, the Corporation apparently being anxious by means of measures of retrenchment to counter any public criticism to the effect that television is subsidizing sound radio. The significance of this development is further enhanced when it is borne in mind that there is a public of about $17,000,000$ which still only has access to sound

${ }^{81}$ Cf. London County Council v. Attorney General, [1902] A.C. 165.

${ }^{22}$ Cf. London Passenger Transport Board v. Mossop, [1942] A.C. 332, 34x.

${ }^{38}$ Cf. Cutler v. Wandsworth Stadium, [1949] A.C. 398.

st News Chronicle (London), Aug. 14, 1957.

${ }^{35}$ See Economist, Aug. I7, 1957, p. 533. It is also worth noting that commercial television, which began by suffering heavy losses, as was generally anticipated by informed opinion, has now begun to pull itself "out of the red." Thus, Associated Television, who put on commercial programs from London at weekends and from Birmingham in midweek, made a loss of $f_{6} 600,000$ in its first 15 months, but in its second year of operation has returned a profit of $\oint_{200,000}$ (see The Times (London), Aug. 5 , 1957, and Aug. 21, 1957. 
radio sets. ${ }^{36}$ Moreover, the financing of sound radio, as, indeed, of noncommercial television as well, has been rendered more difficult owing to the rise in the cost of programs, due partly to general inflation, and also, more specifically, to the competitive demand between the $\mathrm{BBC}$ and commercial television for the same staff and the same artists and other providers of programs. There are already hints of pressure in favor of helping to finance sound broadcast by introducing commercial advertising, but so far, there are no direct signs of any governmental support for breaking the BBC's remaining monopoly in the broadcasting world.

Very relevant, however, to the question of the ousting of sound broadcasting by television is the matter of the cultural level of broadcasting. So far as concerns the standard of broadcasting in television programs, the Act itself, as has been pointed out, seeks to prevent some of the evils that were apprehended by that section of the public which feared that once the gates were lowered to commercialism, a cultural Gresham's Law would operate, the higher level type of program being driven out by the all-powerful demand for more and more mass entertainment. Principally, it was feared that the $\mathrm{BBC}$, which hitherto had not necessarily been moved by the fact that a particular program had had only a minority appeal, might find itself constrained to adapt itself to a new demand to limit broadcasting to those items which possessed a mass appeal. On the whole, however, it cannot be said that this trend, even if perceptible, has, as yet, gone very far. It is true that despite the statutory aspiration towards balanced programs, little has been heard since the commencement of commercial television of such projected programs as symphony concerts. ${ }^{37}$ Yet, the truth may well be that television is hardly the ideal medium for such items; on the other hand, there is, as one would naturally expect, a marked preference shown by commercial television for such mass appeal items as "quiz shows" (particularly linked with the giving away of substantial prizes) ${ }^{38}$ and for variety performances. ${ }^{39}$ But genuine attempts have been made to avoid the more intrusive and offensive type of advertising, and there has been little complaint on this score.

It is rather on sound broadcasting that television casts its darkest shadow. Here it must be admitted that the $\mathrm{BBC}$ has acquired over the years a unique reputation for producing well-balanced programs catering to minority as well as mass tastes. Thus, the $\mathrm{BBC}$ has played a great role in arousing public interest in classical, and even, to some, if a lesser extent, in modern music. More particularly, its Third Program,

${ }^{80}$ As at the beginning of September I957. The actual range of television has been continuously extended by the opening of new stations and will soon cover practically the whole country. The BBC has stated that its television is already available to 97 per cent of the population of the United Kingdom. See The Times (London), Sept. 19, I957.

${ }^{87}$ Concerts by the Halle Orchestra were given at first and are shortly to be resumed.

${ }^{38}$ The Act is particularly inept on this point since it merely prohibits the giving of prizes which are available "only to persons receiving that programme." $2 \& 3$ ELIZ. 2, c. 55, $53(3)$. As the prizes are given not to persons receiving the program, but to individuals participating in it, this provision is obviously irrelevant. What practical situation it does intend to legislate for is far from clear.

${ }^{30}$ The BBC, which has also shown some partiality for "panel games" (though not for prizes), has just announced its intention of indulging in the experiment of replacing these for a few months by more serious programs See News Chronicle (London), Sept. 3, 1957. 
though not free from criticism on account of its "high-brow" or "egg-head" bias, has done much, and earned wide praise thereby, to bring before the public many items of undoubted value, though lacking in mass appeal, such as certain types of plays, poetry, modern and early music, and so forth. The vast and increasing reduction in the number of sound listeners undoubtedly constitutes a direct threat to this class of program, and the $\mathrm{BBC}$ has recently, as part of its policy of retrenchment, announced severe cuts in the broadcast times of the Third Program, as well as substantial changes in its other services. Admittedly, the BBC has declared that it has no intention of abandoning its cultural mission, ${ }^{40}$ but much informed opinion in this country sees this as the thin end of the wedge and foresees, with increasing gloom, the transformation of all broadcasting into a medium of mass appeal. At the root of all this lies the inescapable problem of finance, and it may well be that, unless the country is prepared to face some substantial measure of subsidization for sound broadcasting, the increasing encroachment of television will spell its doom, at any rate in the form at present known to us. Nor can it be said that commercial sound broadcasting is likely to provide an effective answer to this challenge, for even if commerce could, at this stage, be persuaded to take an interest in sound broadcasting, it is hardly likely that this could be achieved without further increasing its mass appeal at the expense of the less popular items. A possible compromise might be to hand over the lighter programs to commercial interests, while leaving the $\mathrm{BBC}$ to cater for the remainder. The danger here would be that the $B B C$ would find itself more and more a minority concern, fighting a losing battle to retain its hold on ever-shrinking funds.

\footnotetext{
${ }^{40}$ See, for a statement of the BBC's intentions, The Times (London), Aug. 2I, 1957.
} 